\title{
Pendidikan Karakter dalam Cerita Gadis Pengusaha Korek Api Karya Watiek Ideo
}

\author{
Endah Imawati \\ IKIP Widya Darma \\ endahimawati@gmail.com
}

DOI: http://dx.doi.org/10.32528/bb.v5i1.3034

Diterima: 20-02-2020 Diterbitkan: 30-03-2020

\begin{abstract}
ABSTRAK
Anak membutuhkan bacaan yang tidak hanya penting, tetapi juga menarik. Peranan bacaan anak dalam pembentukan karakter anak sangat penting. Pendidikan karakter dibutuhkan sebagai dasar pendidikan di Indonesia. Bacaan itu harus menarik tanpa berkesan menggurui. Dongeng klasik yang sering dibaca atau didengar anak kadang-kadang meninggalkan kesan menyedihkan karena sang tokoh tidak berdaya. Dalam cerita "Gadis Pengusaha Korek Api" karya Watiek Ideo, tokohnya justru dibuat berdaya. Tujuan penelitian ini adalah untuk mengidentifikasi perjuangan tokoh utama dalam meraih yang diinginkannya. Anak memerlukan proses untuk meraih cita-cita. Perjuangan itu membutuhkan kreativitas dan kerja keras. Yang menjadi penelitian ini adalah cerita "Gadis Pengusaha Korek Api" yang dibuat berdasarkan cerita klasik "Gadis Penjual Korek Api" karya H.C. Andersen, dengan berdasarkan tiga komponen karakter baik, yaitu moral knowing, moral feeling, dan moral action yang diprakarsai Thomas Lickona. Penelitian deskriptif kualitatif ini menggunakan teknik analisis isi. Pendekatan yang digunakan adalah konsep sastra anak dan pendidikan karakter. Pendidikan karakter untuk anak lebih mudah dipahami melalui cerita bergambar. Tiga komponen karakter baik itu ditemukan tokoh melalui proses yang cerdik. Kecerdikan itu yang menjadikan pesan dalam buku dipahami pembaca. Tokoh utama menunjukkan kegigihan mencapai cita-cita dan tidak mau menderita seperti tokoh dalam dongeng klasik. Strategi yang dia lakukan berhasil mendatangkan keuntungan materi dan memiliki banyak teman baru. Dalam perspektif kewirausahaan, itu menjadi contoh sederhana.
\end{abstract}

Kata Kunci : pendidikan karakter; moral; sastra anak

\begin{abstract}
Children need books that are not only important, but also interesting, to read. The stories should be fun to learn with so they do not feel like being told what to do by the adults. The role of children's reading in shaping children's character is very important. Character education is needed as a basis for education in Indonesia. Nevertheless, the classic fairy tales that are often read or heard by children sometimes give a sad impression to
\end{abstract}


them. It is because the main character is described as a weak person. The struggle requires creativity and hard work. The method is quite different in the story of "The Matches Entrepreneur Girl" by Watiek Ideo. Its main character is narrated as a strong person. The story itself was written based on "The Little Match Girl" by H.C. Andersen. The purpose of this study is to identify the main character's struggle in achieving what she wants. Without the struggle part, the main character's story might be similar to the classic one. Besides, children need a process to achieve their goals. They can learn about the process from it. The object of this qualitative research is the story of "The Matches Entrepreneur Girl" based on the three components of good character initiated by Thomas Lickona. Those are knowing moral, feeling moral and action moral. Character education for children is easier to understand through picture stories. The main character in the story found these three components in a smart process. That ingenuity is the message which can be perceived by the readers. The main character shows the persistence of reaching the ideals and does not want to suffer like a character in a classic fairytale. His strategy succeeded in bringing material benefits and having many new friends. In an entrepreneurial perspective, it becomes a simple example.

\section{Keywords: character education; moral; children's literature}

\section{PENDAHULUAN}

Pendidikan karakter berperan besar atas situasi yang terjadi saat ini. Perilaku baik dalam masyarakat dibentuk dengan memberikan contoh nyata terutama kepada anak karena pada usia dinilah, karakter itu dibentuk. Karakter terjadi melalui proses panjang.

Salah satu cara untuk membentuk perilaku baik sejak kecil adalah melalui karya sastra. Anak dapat belajar tentang karakter yang menurutnya patut dicontoh dari kebiasaan mendengarkan cerita dan membaca. Anak dapat meneladani tokoh-tokoh yang baik dalam cerita. Ada banyak teladan bagik yang bisa disampaikan melalui cerita. Para tokoh di dalam cerita dapat mewakili sikap-skiap baik itu.

Sastra berkontribusi sastra terhadap kemajuan peradaban umat manusia pada masa kini, terutama pada masa mendatang (Faidah, 2018, p. 131). Sastra anak yang baik dan berkualitas akan memberi dampak dalam banyak dimensi pada kehidupan anak saat ini yang akan berpengaruh juga pada masa mendatang. Itu karena sastra anak memberikan kontribusi pada rasa sosial, imajinasi, dan intelektual anak. Selain itu, sastra untuk anak juga memengaruhi perkembangan emosional anak, membentuk kepribadian luhur, dan membangun kreativitas anak.

Sastra dapat digunakan untuk mengenalkan nilai-nilai seperti moral, budaya, dan pendidikan yang dianut oleh masyarakat. Syarat dalam penulisan cerita anak adalah cerita yang menggugah rasa ingin tahu sekaligus dekat dengan pembacanya (Sarumpaet, 2003; Suyatno, 2009, p. 29). Di luar teks, sebaiknya penulisan buku anak haruslah mengingat faktor pembacanya. Faktor tersebut adalah (1) tokoh cerita dapat diterima anak-anak sebagai tokoh identifikasi karena sesuai dengan perilaku anak-anak lainnya sebagai pembaca, penyajian langsung menuju sasarannya, dan ada fungsi serapan, (2) terdapat pengesanan terhadap tokoh menurut jenisnya, dan (3) terdapat perhatian anak dalam penyajian cerita dan tokoh. 
Selain menggugah rasa ingin tahu, cerita anak juga memiliki peran sebagai salah satu alat pendidikan yang seharusnya dimanfaatkan dalam dunia pendidikan untuk mengembangkan kepribadian anak dan berperan sebagai pembentukan karakter (Nurgiyantoro, 2010, p. 32). Sastra memiliki peran dalam usaha pembentukan dan pengembangan kepribadian anak. Agar dapat menjadi sarana pembentukan dan pengembangan kepribadian anak, diperlukan strategi yang benar pula, yaitu dengan cara yang menyenangkan. Usaha pembentukan kepribadian lewat kesastraan tersebut berlangsung secara tidak langsung sebagaimana halnya pembelajaran etika, normanorma, agama, budi pekerti, atau yang lain.

Sastra anak berperan besar terhadap perkembangan kepribadian anak dalam proses menuju ke kedewasaan. Kepribadian dan atau jati diri seorang anak dibentuk dan terbentuk lewat lingkungan, baik diusahakan secara sadar maupun tidak sadar. Sastra dapat menjadi sebagai salah satu sarana untuk menanamkan, memupukkan, mengembangkan, dan bahkan melestarikan nilai-nilai yang diyakini baik dan berharga oleh keluarga, masyarakat, dan bangsa. Dengan pewarisan nilai-nilai itulah, masyarakat atau bangsa dapat mempertahankan eksistensinya.

\section{METODE PENELITIAN}

Penelitian ini menggunakan pendekatan kualitatif dengan kajian tekstual yang tidak memasukkan resepsi pembaca maupun intervensi pengarang. Apa yang muncul sebagai hasil saat mengumpulkan data dikonsentrasikan pada teks. Penelitian ini berfokus pada pengenalan pendidikan karakter pada anak melalui cerita. Pilihan kata yang tepat untuk menjelaskan maksud menjadikan pendidikan karakter mudah disampaikan kepada anak.

Pendekatan kualitatif adalah suatu proses penelitian dan pemahaman yang berdasarkan pada metodologi yang menyelidiki suatu fenomena sosial dan masalah manusia. Pada pendekatan ini, peneliti membuat suatu gambaran kompleks, meneliti kata-kata, laporan terpeinci dari pandangan responden, dan melakukan studi pada situasi yang alami (Creswell, 1998, p. 15).

Sumber data penelitian ini cerita anak "Gadis Pengusaha Korek Api" karya Watiek Ideo. Di dalamnya terdapat cerita tentang keinginan anak untuk menambah penghasilan agar tidak seperti tokoh dalam cerita "Gadis Korek Api" yang meninggal karena kedinginan. Ia tidak berhasil menjual korek api.

\section{PEMBAHASAN}

Anak-anak seharusnya mendapat media yang tepat untuk memenuhi kebutuhan mereka akan mengetahui dan memahami sesuatu. Buku-buku bacaan sastra bagi anak bermanfaat mengolah jiwa dan kepekaan anak agar mendorong mereka tumbuh menjadi manusia yang berkarakter kuat, sekaligus halus perasaannya. Pembentukan karakter harus dilakukan secara sistematis dan berkesinambungan yang melibatkan aspek knowledge, feeling, loving, dan acting (Irawati, 2013, p. 47).

Aspek pengetahuan mengenai perilaku yang baik dan diyakini baik oleh masyarakat dikenalkan kepada anak. Selanjutnya, anak akan memiliki perasaan nyaman 
dengan pilihan perilaku itu karena ia dikuatkan oleh lingkungan untuk melakukannya. Pada tahap selanjutnya, dibutuhkan sikap penuh kasih kepada sesama dan lingkungannya hingga kemudian anak dapat bersikap dan berperilaku baik karena ia telah melewati semua tahap itu dalam proses perkembangannya.

Anak memerlukan cerita realistik (Sarumpaet, 2010, p. 28). Anak menikmati penggambaran yang dapat mendekatkan mereka pada kehidupan yang nyata (Zizek, 2008, p. 103). Segala sesuatu yang terjadi dalam cerita realistik mungkin saja terjadi dalam kehidupan. Para tokoh, persoalan, latar yang ada di dalamnya mengingatkan, menunjuk, dan merujuk pada sesuatu yang dapat dikenali anak-anak.

Sarumpaet menambahkan, jika akan akan mencari karakter bangsa Indonesia, kembalilah ke keluarga. Diperlukan pencarian genealogi bangsa untuk membangun karakter anak. Itu adalah pekerjaan utama untuk masa depan bangsa. Diperlukan pengenalan nilai-nilai universal sebagai bangsa yang heterogen. Nilai itu harus menghasilkan perilaku dan berdampak positif bagi yang menjalankan dan bagi orang lain. Nilai yang berdampak pada orang lain adalah setia, dapat dipercaya, hormat, cinta kasih sayang, peka, tidak egois, baik hati, ramah, adil, dan murah hati. Itu dapat disampaikan melalui sastra anak.

Sebagai program nasional, pengenalan pendidikan karakter seharusnya menciptakan sekolah yang mendorong etika, bertanggung jawab, dan peduli orang muda dengan pemodelan dan mengajarkan karakter yang baik melalui penekanan pada nilai-nilai universal bahwa semua mau berbagi. Nilai-nilai etika itu seperti kepeduian, kejujuran, keadilan, tanggung jawab, dan penghargaan terhadap diri dan orang lain (Lestari, 2019, p. 179).

Pengenalan karakter baik dapat dilakukan melalui buku cerita. Anak menyukai buku cerita. Salah satu jenis cerita anak adalah buku cerita bergambar. Buku cerita bergambar memiliki ilustrasi yang berperan penting dalam keseluruhan alur cerita. Early picture books menjadi salah satu pilihan yang tepat untuk anak kelas awal. Early picture books adalah jenis buku cerita bergambar yang menjadi bacaan penting untuk anak (Kurniawan, 2009, p. 31). Melalui buku cerita bergambar, anak dapat menikmati karakter dan kisah di dalam buku.

Early picture books merupakan buku cerita bergambar untuk anak yang mulai membaca sendiri, sekitar usia 6-8 tahun. Cerita disampaikan dengan aksi dan percakapan interaktif. Kalimat yang digunakan kalimat sederhana. Satu gagasan cukup diwakili satu kalimat. Setiap halaman memiliki 2-5 kalimat.

Cerita "Gadis Pengusaha Korek Api" adalah early picture books dengan jumlah kata 270 kata karena pengulangan frasa gadis penjual korek api yang cukup panjang dan berulang. Sebagai cerita untuk anak, "Gadis Pengusaha Korek Api" menunjukkan pendidikan karakter sang tokoh yang berjuang mewujudkan cita-citanya. Tokoh itu harus berusaha supaya dia bisa menjadi pemenang, sesuai dengan target yang diinginkannya. Secara moral, tokoh menunjukkan sisi positif dari semua usahanya.

Bukan sumber daya alam yang melimpah atau luas geografis serta jumlah penduduk berlimpah yang dapat menentukan kemajuan bangsa, melainkan faktor budayalah yang menyangkut nilai dan karakter yang menentukannya. Faktor budaya, 
nilai-nilai yang berlaku, dan ciri khas watak masyarakat suatu negara sangat menentukan keberhasilan pembangunan ekonominya. Faktor budaya yang dicerminkan oleh karakter dan perilaku masyarakatnya sering disebut modal sosial, yaitu modal yang harus dimiliki sebuah negara untuk bisa maju

Pembentukan karakter idealnya dimulai sejak kecil. Karakter manusia ditentukan oleh nature (faktor alami) dan nurture (sosialisasi dan pendidikan) (Suyatno, 2009, p. 34). Memiliki akhlak mulia tidak secara otomatis dimiliki oleh setiap manusia begitu ia dilahirkan. Diperlukan proses panjang melalui pengasuhan dan pendidikan. Anak-anak yang berkarakter baik adalah mereka yang memiliki kematangan emosi dan spiritual tinggi sehingga dapat mengendalikan stres dengan lebih baik yang akhirnya meningkatkan kesehatan fisiknya.

Dalam pendidikan karakter, Lickona, Schaps, \& Lewis (2013, p. 45) menekankan pentingnya tiga komponen karakter yang baik, yaitu moral knowing atau pengetahuan tentang moral, moral feeling atau perasaan tentang moral, dan moral action atau perbuatan bermoral. Moral knowing adalah aspek yang penting untuk diajarkan yang terdiri atas moral awareness (kesadaran moral), moral knowing (mengetahui nilai-nilai moral), perspective taking (pengambilan keputusan).

Moral feeling adalah aspek yang harus ditanamkan kepada anak untuk bertindak sesuai dengan prinsip-prinsip moral. Terdapat enam hal yang merupakan asek emosi yang harus mampu dirasakan oleh seseorang untuk menjadi manusia berkarakter, yaitu nurani, percaya diri, empati, mencintai kebenaran, mampu mengontrol diri, dan kerendahhatian.

Nilai karkater berhubungan dengan diri sendiri, yaitu berjiwa wirausaha, percaya diri, bekerja keras, berpikir logis, jujur, bertanggung jawab, mandiri, dan disiplin (Khaironi, 2017, p. 84).

Moral action adalah perwujudan pengetahuan moral ke dalam tindakan nyata. Itu dapat dilihat dari karakter kompetensi, keinginan, dan kebiasaan.

Orang tua memiliki peran besar terhadap anak-anaknya. Keluarga menjadi sekolah yang pertama dan utama bagi anak-anak. Buku untuk anak dengan muatan sastra menjadi salah satu cara untuk mengenalkan pengetahuan moral pada anak.

Penggunaan buku-buku cerita dapat menumbuhkan rasa kecintaan anak terhadap kebajikan. Peran buku cerita sangat besar terhadap pendidikan karakter. Cerita-cerita yang bagus akan memperluas pikiran dan hati anak. Anak perlu diberi bacaan yang jelas moralnya seperti buku yang betujuan mengajarkan betapa pentingnya menolong dan menyenangkan orang lain, tentang usaha keras ntuk berbuat kebaikan, dan sebagainya. Buku cerita dapat menumbuhkan rasa empati. Selain itu, buku cerita tentang tokohtokoh berkarakter akan memberikan contoh yang bagus untuk anak tentang cara menjadi orang berkarakter. Pembinaan karakter harus terus dilakukan secara holistik. Itu dilakukan baik di dalam keluarga, sekolah, dan masyarakat. (Cahyaningrum, Sudaryani \& Purwanto, 2017, p. 212).

Cerita anak menawarkan kesenangan dan pemahaman dan hadir kepada pembaca untuk memberi hiburan yang menyenangkan. Bacaan anak mampu menstimulasi imajinasi anak, mampu membawa ke pemahaman terhadap diri sendiri dan orang lain. 
Jika citraan atau metafora kehidupan yang dikisahkan berada dalam jangkauan anak, baik yang melibatkan aspek emosi, perasaan, pikiran, saraf sensori, maupun pengalaman moral, dan diekspresikan dalam bentuk-bentuk kebahasaan yang juga dapat dijangkau dan dipahami oleh pembaca anak-anak, buku atau teks tersebut dapat diklasifikasikan sebagai sastra anak.

Pernyataan itu terdapat dalam data Ideo (2014, p. 7). Tokoh utamanya anak perempuan penjual korek api yang berumur sekitar 8 tahun dan tidak disebut namanya. Ia tinggal di desa yang tenang. Desa itu ada di negara empat musim. Saat musim dingin itu, ia harus tetap menjual korek apinya. Kisah anak perempuan itu mengingatkan pada cerita klasik "Gadis Penjual Korek Api" yang meninggal kedinginan. Gadis itu tidak memiliki cukup uang untuk membeli makanan atau sekadar menghangatkan tubuh.

Pesan dari kisah klasik itu yang ingin diubah oleh Watiek Ideo sehingga gadis penjual korek apinya adalah gadis yang berdaya. Watiek membangun karakter kuat dan pantang menyerah pada tokoh utamanya bahkan ketika korek apinya tidak laku. Itu tampak pada data-data berikut.

"Oh! Aku tak mau hidupku seperti temanku yang meninggal karena kedinginan...," bisiknya.

Dia pun berpikir keras hingga menemukan sebuah ide cemerlang. Bergegas dihampirinya satu anak perempuan yang asyik duduk di taman. "Halo apalah kamu mau membantuku?" (p. 6-9)

"Kalau kamu bisa menjual korek-korek ini, aku berjanji akan membagi keuntungannya denganku," kata gadis penjual korek api. (p. 10)

Data itu menunjukkan kemauan dan kemampuan tokoh untuk mencari cara agar hidupnya selamat, berbeda dengan kisah gadis penjual korek api dalam dongeng klasik H.C. Andersen. Ia memahami, jika menjual sendiri, kecil kemungkinan bisa menjual korek api lebih banyak. Itu sebabnya, ia berkolaborasi dengan orang lain. Ide itu sederhana, tetapi memiliki makna mendalam. Gadis penjual korek api meminta tolong pada anak perempuan lain. Dia minta tolong dengan santun dan memberikan janji membagi sebagian keuntungan.

"Kamu boleh mengajak teman-temanmu yang lain dengan keuntungan yang sama. Tentu saja kamu akan mendapat bonus dariku," kata gadis penjual korek api. (p. 10)

Data itu menunjukkan kecerdikan tokoh utama. Ia sudah bisa menghitung kemungkinan keuntungan yang akan dia dapat serta membagi bonus. Jiwa wirausahanya muncul dengan cara sederhana.

Bukan hanya tentang pembagian keuntungan, gadis penjual korek api juga membagi wilayah. Siapa berjualan di sebelah timur desa dan siapa berjualan di sebelah barat desa. 
Tokoh utama menunjukkan karakter kreatif dan kerja keras ditunjukkan dengan sikap pantang menyerah. Ketika meraih sesuatu, anak diajak untuk kreatif dan tidak berputus asa. Ide yang kreatif dan usaha yang tidak berhenti menjadi wujud penanaman nilai itu (Juanda, 2018, p. 14).

Tokoh utama juga bertemu dengan teman-temannya yang lain. Ia juga mengajak mereka berjualan di tempat berbeda.

Menjelang sore, semua penjual korek api berkumpul di taman kota.

"Tadi korek apiku laku 10 bungkus di timur desa."

"Aku juga bisa menjual 5 bungkus di selata!"

"Eh, di pinggir desa, aku berhasil menjual 27 bungkus korek api!"

"Besok lagi, ya," kata anak-anak itu dengan gembira.

"Ya, mumpung sekolah kita libur." (p. 10-12)

Kesuksesan itu membuat para penjual korek api senang. Gadis penjual korek api menepati janji, yaitu membagi keuntungan. Data itu sesuai dengan nilai moral yang dituturkan Lickona, yaitu moral feeling. Anak bertindak sesuai dengan prinsip-prinsip moral, yaitu nurani, percaya diri, empati, mencintai kebenaran, mampu mengontrol diri, dan kerendahhatian. Tokoh utama dengan percaya diri meminta tolong orang lain untuk membantu menjualkan korek api. Ia juga mampu mengontrol diri dengan tidak serakah mengambil seluruh keuntungan. Tokoh menepati janji untuk membagi keuntungan.

Itu menjadi salah satu kecerdasan moral bagi anak, yaitu memiliki keyakinan etika yang kuat dan berbiat berdasarkan kepercayaan itu sehingga ia berskap benar dan terhormat (Vardani, 2018, p. 25).

Sikap rendah hati juga ditunjukkan tokoh utama dengan berterima kasih kepada semua yang telah menjualkan korek api. Secara logika, tokoh utama menolak kondisi yang membuat orang lain sesama penjual korek api seperti dalam kisah dongeng klasik menderita. Ia ingin keluar dari stigma kisah klasik itu. Gadis penjual korek api dapat menentukan jalan hidupnya dengan cara sederhana.

Selain itu, moral action yang menjadi perwujudan pengetahuan moral ke dalam tindakan nyata juga dilakukan tokoh utama. Itu dapat dilihat dari karakter kompetensi, keinginan, dan kebiasaan.

Tokoh utama tidak sendirian. Anak-anak lain juga ingin mendapatkan keuntungan. Itu adalah sikap yang wajar karena anak membutuhkan kompetisi yang wajar untuk mencapai kemenangan. Tokoh utama juga demikian. Akan tetapi, ia sudah berpikir layaknya pelaku usaha, yaitu membagi wilayah agar semua mendapat kesempatan menjual korek api.

Isi kandungan sastra anak dibatasi oleh pengalaman dan pengetahuan yang dijangkau, dipahami, dan sesuai dengan dunia anak. Menurut Huck (dalam Nurgiyantoro, 2005:7), sastra anak adalah cerita yang menempatkan sudut pandang anak sebagai pusat penceritaan. 
"Oh! Aku tidak mau hidupku seperti temanku yang meninggal karena kedinginan...," bisiknya.

Dia pun berpikir keras. (p. 6)

Data itu menunjukkan kemauan kuat untuk mewujudkan target. Tokoh utama menunjukkan niatnya itu dengan menggandeng temannya dan teman-teman barunya untuk menjual korek api di wilayah yang berbeda.

Kegembiraan anak-anak setelah berhasil menjual korek api tampak ketika mereka dengan bangga menyebutkan angka penjualan. Mereka bersemangat kembali untuk menjual korek api setelah mendapatkan pembagian keuntungan seperti janji di awal. Mereka memupuk kepercayaan kepada gadis penjual korek api. Gadis itu juga menjaga kepercayaan teman-temannya dengan menepati janji.

Karena hidup di dalam masyarakat yang majemuk, kesadaran bahwa ada berbagai perilaku yang kadang-kadang melukai anak, sebaiknya ditanamkan sejak dini kepada anak. Pengenalan itu salah satunya melalui bacaan yang mendemonstrasikan perbedaan lewat sikap dan pengalaman tokoh (Hunt, 2001, p. 74). Sastra dapat dipahami sebagai penggambaran secara konkret tentang model-model kehidupan sebagaimana yang dijumpai dalam kehidupan lewat karakter tokoh dan alur cerita.

Keuntungan tidak datang begitu saja. Semua harus berusaha. Itu sebabnya, ketika gadis penjual korek api dan temannya bersepakat untuk menjual di wilayah berbeda, moral feeling dan moral action sudah muncul. Mereka harus berusaha untuk mencapai target, yaitu korek apinya laku. Mereka berteriak-teriak menjajakan korek api.

"Yuk! Kita langsung berjualan!"

"Korek api! Korek api!"

Suara mereka bersahut-sahutan. (p. 11)

Data di muka menunjukkan bentuk kekuatan tokoh utama untuk mewujudkan cita-cita. Ia menyadari, cita-cita itu tidak datang begitu saja. Ia harus mencari cara agar bisa mewujudkannya. Caranya adalah dengan berkolaborasi. Kegigihan tokoh utama menjadi cara mudah bagi pembaca untuk belajar dari tokoh utama tentang kesungguhan mewujudkan cita-cita dengan cara benar dan bersih.

Itu sesuai dengan nilai karakter yang berhubungan dengan diri sendiri, yaitu berjiwa wirausaha, percaya diri, bekerja keras, berpikir logis, jujur, bertanggung jawab, mandiri, dan disiplin (Khaironi, 2017, p. 84).

Sastra anak, betapa pun dimaksudkan untuk menghibur, tetap saja bersifat mendidik. Justru karena sifat itulah dengan mempertimbangkan perkembangan anak secara psikologis, pedagogis, dan memperhatikan segala keperluan dan lingkup kehidupan khasnya, ranah itu menjadi istimewa (Sarumpaet, 2010, p. 12).

Syarat sastra yang menghibur adalah menyenangkan. Ciri utama menyenangkan ini antara lain tampak pada penggunaan bahasa yang segar sesuai dengan bahasa anakanak. Kedua, seluruh unsurnya fungsional. Syarat ketiga adalah adanya kejutan yang erat kaitannya dengan ciri menyenangkan. Keempat, memberi pengalaman baru tentang 
suatu hal dengan perspektif lain. Kesadaran itu tidak muncul tiba-tiba, tetapi melalui proses yang logis.

Banyak ditemukan kisah realistis ataupun fanatasi (seperti dongeng) atau campuran kisah itu sepenuhnya digunakan sebagai alat untuk menjejalkan kehendak orang dewasa. Kisah direkayasa agar secara cepat menjadi resep atau petunjuk teknis bagaimana berperilaku (Sarumpaet, 2018, p. 231).

Tokoh utama belajar dari kondisi yang dialami gadis penjual korek api yang meninggal kedinginan. Ia tidak ingin mengulangsi kisah itu. Penulisnya dengan tegas menolak akhir cerita yang mengenaskan. Tokoh utama harus memiliki daya untuk membuat perbaikan sehingga dia tidak tersia-sia.

Usaha yang dilakukan tokoh utama menghasilkan keuntungan. Penutup itu menunjukkan pesan tentang hasil yang harus diperoleh melalui usaha. Usaha yang dilakukan tokoh utama tidak mudah. Ia harus menjual dagangannya. Akan tetapi, usaha itu juga berupa pemikiran untuk menjadikan dagangannya menghasilkan keuntungan. Berkolaborasi menjadi ide yang diwujudkan tokoh utama. Dengan berkolaborasi, ia dapat menjual lebih banyak lagi. Selain itu, tokoh utama memiliki banyak teman baru.

Kelak, ia akan dikenal sebagai gadis pengusaha korek api yang sukses dan kaya. (p. 17)

Ada hal-hal yang harus muncul dalam sastra anak. Kesatu, keteladanan yang logis. Maksudnya, tokoh hero haruslah hadir sebagai hero secara logis. Kehadirannya bisa diterima akal sehat. Kedua, karya sastra yang mendidik harus tetap menghibur. Ketiga, unsur petualangan atau eksplorasi. Eksplorasi memberi pengalaman baru. Ketiga hal itu berkaitan erat. Karya sastra yang menyenangkan di dalamnya sering ada keteladanan dan ada petualangan-petualangan. Keteladanan itu menyenangkan, begitu pula dengan petualangan yang juga harus menyenangkan.

Dalam perkembangan selanjutnya setelah anak dapat memahami cerita, baik diperoleh lewat pendengaran misalnya diceritai atau dibacakan, maupun lewat kegiatan membaca sendiri, anak akan memperoleh pelajaran seperti yang diperagakan oleh para tokoh cerita. Tokoh cerita juga menunjukkan sikap emosionalnya, seperti ekspresi gembira, sedih, takut, terharu, simpati dan empati, benci dan dendam, memaafkan, dan lain-lain secara kontekstual sesuai dengan alur cerita (Goga, 2018, p. 59). Pembaca anak akan mengidentifikasikan dirinya kepada tokoh sehingga sikap dan tingkah laku tokoh itu seolah-olah diadopsi menjadi sikap dan tingkah lakunya.

\section{SIMPULAN}

Cerita "Gadis Pengusaha Korek Api" menjadi cerita yang sesuai untuk anak usia 6-8 tahun karena di dalamnya terdapat pendidikan karakter yang dapat mengajak anak belajar menguatkan moral knowing, moral feeling, dan moral action. Itu yang mengasah nurani, percaya diri, empati, mencintai kebenaran, mampu mengontrol diri, dan kerendahhatian. 
Alih-alih membalik kisah dari dongeng klasik bertopik sama, tokoh utama menunjukkan kegigihan mencapai cita-cita dan tidak mau menderita seperti tokoh dalam dongeng klasik. Tidak ada yang instan jika ingin mewujudkan cita-cita itu. Tokoh utama menunjukkan proses cerdik dalam pemasaran. Strategi yang dia lakukan berhasil mendatangkan keuntungan materi dan memiliki banyak teman baru. Dalam perspektif kewirausahaan, itu menjadi contoh sederhana yang dapat ditangkap pembaca.

Selain menjadi buku sastra anak, "Gadis Pengusaha Korek Api" dapat menjadi rujukan untuk mengajarkan kewirausahaan melalui cara sederhana tanpa meninggalkan sikap moral yang mendasarinya. Anak-anak belajar gigih berusaha, cerdik, dan pantang menyerah.

\section{UCAPAN TERIMAKASIH}

Terima kasih kepada pimpinan kampus IKIP Widya Darma yang telah mendorong penelitian tentang sastra anak untuk mendukung program mata kuliah Sastra Anak.

\section{DAFTAR RUJUKAN}

Cahyaningrum, E. S., Sudaryanti, \& Purwanto. (2017). Pengembangan nilai-nilai karakter anak usia dini melalui pembiasaan dan keteladanan. Jurnal Pendidikan Anak, 6, 203-213.

Faidah, C.N. (2018). Dekonstruksi sastra anak: mengubah paradigma kekerasan dan seksualitas pada karya sastra anak Indonesia. Jurnal Kredo, 2, 198-203.

Goga, N. (2018). Ecocritical perpectives on children's texts and cultures. Switzerland: Palgrave Macmillan.

Hunt, P. (2001). Children's literature. Massachusetts: Blackwell Publisher Inc.

Ideo, W. (2014). Kumpulan dongeng nyentrik, asyik, dan menggelitik. Jakarta: Bhuana Ilmu Populer.

Irawati, R.P. \& Purwani, N. (2013). Nilai-nilai moralitas dan budaya asing dalam sastra anak terjemahan melalui pemaknaan sastra anak oleh anak. Lingua, 9, 4555 .

Juanda. (2018). Revitalisasi nilai dalam dongeng sebagai wahana pembentukan karakter anak usia dini. Jurnal Pustaka Budaya (5) 11-18.

Khaironi, M. (2017). Pendidikan karakter anak usia dini. Jurnal Golden Age Universitas Hamzanwadi, (1) 82-89.

Kurniawan, H. (2009). Sastra anak. Jogjakarta: Graha Ilmu.

Lestari, R.F. (2019). Wujud budaya dan pendidikan karakter dalam cerita rakyat Watu Dodol. Belajar Bahasa, 4, 161-240.

Lickona, T., E. Schaps, \& C. Lewis. (2003). Eleven principles of effective character education. Washington, D.C.: Character Education Partnership. 
Nurgiyantoro, B. (2005). Sastra anak. Jogjakarta: Gadjah Mada University Press.

Nurgiyantoro, B. (2010). Sastra anak dan pembentukan karkater. Cakrawala Pendidikan, Edisi Khusus Dies Natalis UNY. Mei. XXIX

Sarumpaet, R.K.T. (2010). Pedoman penelitian sastra anak. Jakarta: Yayasan Penerbit Obor.

Sarumpaet, R.K.T. (2018). Sastra dan pembentukan karakter: antara perkara "yang mulia" dan tak-cerita. Hakikat ilmu pengetahuan budaya. R.S. Hidayat (ed.). Jakarta: Buku Obor.

Suyatno. (2009). Menjelajah pembelajaran inovatif. Surabaya: Masmedia Buana Pustaka.

Suyatno. (2009). Struktur narasi dan kohesi novel karya anak. Surabaya: Jaring Pena.

Vardani, E.N.A. (2018). Penanaman nilai-nilai karakter Islam dalam cerpen aku ingin emak masuk surga karya Maiyade Laila Yane. Belajar Bahasa, 3, 23-37.

Zizek, S. (2008). The sublime object of ideology. London: Verso. 
Imawati, E. Pendidikan Karakter dalam Cerita Gadis Pengusaha... 